NEW BOW-TIE CATIONIC CARBOSILANE DENDRITIC SYSTEM WITH CURCUMIN CORE AS AN ANTI-BREAST CANCER AGENT

Autores

5 Tania Lozano-Cruz,a,b Rafael Gómez,a,b,c F. Javier de la Mata,a,b,c Paula Ortega.a,b,c *

6 Revista, año, volumen, número, páginas

7 NEW JOURNAL OF CHEMISTRY 2018, 42 (14), 11732-11738. DOI: 10.1039/c8nj01713a

8 Available at https://pubs.rsc.org/en/content/articlelanding/2018/nj/c8ni01713a\#!divAbstract

9

10

(c) Editorial

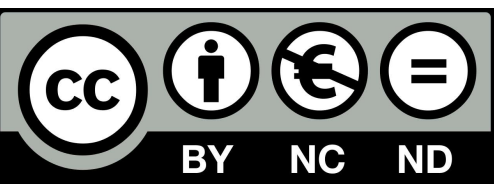

This work is licensed under a Creative Commons Attribution-NonCommercial-NoDerivatives 17 4.0 International License. 
Manuscript submitted to: New Journal of Chemistry

\section{NEW BOW-TIE CATIONIC CARBOSILANE DENDRITIC SYSTEM WITH CURCUMIN CORE AS AN ANTI-BREAST CANCER AGENT}

\section{Tania Lozano-Cruz, ${ }^{\text {a,b }}$ Rafael Gómez, ${ }^{\text {a,b,c }}$ F. Javier de la Mata, ${ }^{\text {a,b,c }}$ Paula Ortega. ${ }^{\text {a,b,c }}$ *}

${ }^{a}$ Departamento de Química Orgánica y Química Inorgánica Universidad de Alcalá, Campus

Universitario, E-28871 Alcalá de Henares, Spain. E-mail: paula.ortega@uah.es. Fax: +34 91 8854679 ,

${ }^{b}$ Networking Research Center on Bioengineering, Biomaterials and Nanomedicine (CIBERBBN), Spain. E-mail: paula.ortega@uah.es

'Instituto Ramón y Cajal de Investigación Sanitaria. (IRYCIS). Ctra. Colmenar Viejo, km. 9, 100 28034 Madrid, Instituto de Investigación Química "Andrés M. del Río" (IQAR), Universidad de Alcalá

\section{Graphical abstract}
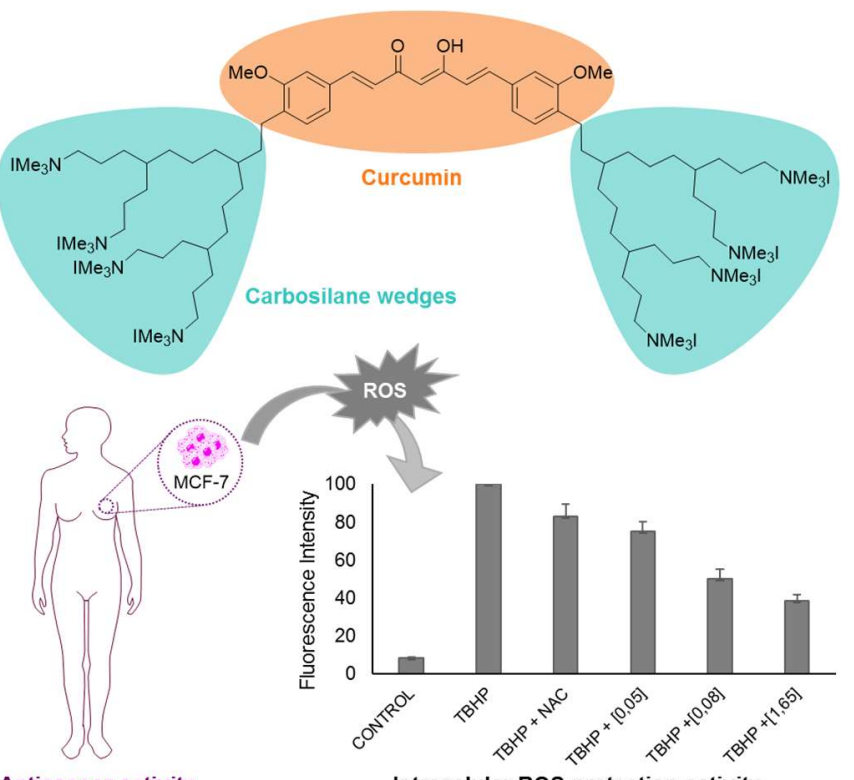

Anticancer activity

Intracelular ROS protection activity

\section{Highlights:}

- A new water soluble "bow-tie" cationic carbosilane dendrimer with curcumin in the core have been synthetized.

- The new derivative present a potent radical-scavenging activity and is more active than free curcumin.

- Is shows a growth-inhibitory activity against breast cancer with a IC50 $=2.75 \pm 0.11 \mu \mathrm{M}$. 


\section{ABSTRACT}

2 Though curcumin has been demonstrated as highly cytotoxic towards various cancer cell lines,

3 the major drawbacks for its use are the insolubility and instability in water to provoke low

4 bioavailability. On the other hand, carbosilane dendritic systems with cationic charge on the

5 surface have been studied in different biomedical applications such as antibacterial, anticancer or

6 as non-viral vehicles for the delivery of nucleic acids. In this study, we combine both systems by

7 synthesizing a new "bow-tie" cationic carbosilane dendrimer where curcumin is located at the

8 core. The resulting new system is completely water-soluble, conserves the antioxidant properties

9 and induces higher cytotoxicity against MCF-7 cancer cells than free curcumin. In addition, the

10 effects on the cell cycle and apoptosis induction by using flow cytometry analysis are evaluated

11 to obtain insights of the cytotoxic mechanism of action.

12 Keywords: curcumin, dendrimers, carbosilane, MCF-7, Antioxidant, antitumoral.

\section{INTRODUCTION}

Breast cancer is the most frequent malignancy among women worldwide that affects 1 in 8 women during their lives. ${ }^{1}$ The main treatments for breast cancer are surgery, radiotherapy, chemotherapy, hormone therapy and targeted therapy., 3 Due to the development of drug resistance, severe side effects, relapses and recurrences of cancer, there is a need to develop new anticancer drugs, less toxic and more comfortable to the patient with potent activity, tissue selectivity and novel modes of action., ${ }^{4,5}$

Curcumin is a hydrophobic natural polyphenol, known for decades, that could act to modulate numerous molecular targets and exerts antioxidant, anti-inflammatory, anticancer, and neuroprotective activities. ${ }^{6-8}$ In the literature, several studies concerning the effect of curcumin against breast cancer showed excellent results inducing cellular apoptosis for both in vitro and in vivo experiments. ${ }^{9}, 10$ However, curcumin has several limitations such as nonspecific biodistribution and targeting, lack of water solubility and poor oral bioavailability and adsorption. Although curcumin could be a potent anticancer agent with remarkable safety profile, all these disadvantages are important parameters to render a compound not suitable as a therapeutic agent. For that reason, it would be desirable to develop carrier platforms that could improve the efficacy and reduce such limitations by specific delivery of the therapeutic agent to the tumor sites and increment of its solubility and bioavailability.

Advances in nanotechnology and materials science have offered new nanostructured systems such as polymers, microparticles, microcapsules, nanoparticles, liposomes, micelles and dendrimers that could allow a decrease of the dosing frequency, lower drug concentration in blood, major bioavailability and reduction of side effects. ${ }^{11,12}$ Most nanoformulations of curcumin with some of these drug delivery systems have been tested successfully and are promising to reach 
1 clinical application. ${ }^{13-17}$. In this approach, dendrimers play an important role because they are

2 highly branched macromolecules, ideally monodisperse that provide many exciting opportunities

3 for the design of novel drug-carriers. They hold promise in tissue targeting applications or

4 controlled drug release and, moreover, their interesting nanoscopic architecture might allow

5 easier passage across biological barriers. ${ }^{18-20}$

6 Our research interest is focused on carbosilane dendrimers which are interesting systems not only

7 because of their chemical and thermal stability, but also for their biocompatibility. We have

8 studied their activity in different biomedical applications such as antiviral, antibacterial,

9 anticancer agents, delivery of nucleic material in gene therapy or in neurodegenerative diseases.

$10 \quad{ }^{21-27}$ There are only a few studies combining dendrimers and curcumin, where the dendrimers used

11 are PAMAM or PPI. ${ }^{28-31}$ In these studies, the dendritic systems were used to encapsulate the

12 curcumin inside of their structure by electrostatic interaction or by covalent attachment of

13 curcumin on the dendritic skeleton, in both case the solubility and bioavailability is improving

14 compared to free curcumin and showing higher anti-proliferative activity against different cells line. Another approach is the covalent attachment of curcumin to dendritic systems. Only one example has been described by modification of curcumin phenol groups with second-generation polyester dendrons and its antioxidant and cytotoxic capacity measured respecting free curcumin. ${ }^{32}$ However, to our knowledge, no studies concerning carbosilane dendritic systems have been published.

Based on this background, the main goal of the work here presented is the functionalization of curcumin with cationic carbosilane dendrons by covalent attachment that permit to combine the unique properties of both systems. The hydrophobic character of the carbosilane skeleton on the one hand would facilitate the passage of the system to the cell through the lipid bilayer and, on the other hand, the cationic terminal groups of the surface promote its solubilization in aqueous medium increasing its bioavailability. In addition, both curcumin and carbosilane dendritic systems containing alcohol or ammonium groups (vide infra) have shown to have anticancer activity, and for this reason a cooperative effect between them may be possible. ${ }^{6,7,23}$

\section{EXPERIMENAL SECTION.}

\subsection{Chemistry General considerations.}

In order to clarify, the carbosilane dendron nomenclature, $\mathrm{XGn}(\mathrm{Y}-\mathrm{Z}) \mathrm{m}]$, is necessary to know that $\mathrm{n}$ indicates the generation of dendritic skeleton formed by carbon-to-carbon and carbon-to-silicon covalent bonds, $\mathrm{X}$ indicate the focal point and $\mathrm{Y}$ indicates functionalization of the periphery by hydrothiolation $(\mathrm{Y}=\mathrm{S})$, and $\mathrm{Z}$ and $\mathrm{m}$ correspond to the peripheral functional groups and their numbers on the surface. 
1 All reactions were carried out under inert atmosphere and solvents were purified from appropriate drying agents when necessary. Compounds, 3-methoxy-4-(2-propyloxy)benzaldehyde and azide-terminated carbosilane wedge $\left(\mathrm{N}_{3} \mathrm{G}_{2}\left(\mathrm{SNMe}_{3} \mathrm{I}\right)_{4}\right.$ II) were prepared by previously reported methods. ${ }^{33,34}$ and the other reagents were obtained from commercial sources and used as received.

\subsection{Methods}

NMR spectra were recorded on a Varian Unity VXR-300 or on a Bruker AV400 $\left(300.13\left({ }^{1} \mathrm{H}\right)\right.$, $\left.75.47\left({ }^{13} \mathrm{C}\right) \mathrm{MHz}\right)$. Chemical shifts $(\delta)$ are given in ppm. ${ }^{1} \mathrm{H}$ and ${ }^{13} \mathrm{C}$ resonances were measured relative to internal deuterated solvents peaks considering TMS $=0 \mathrm{ppm}$. When necessary, assignment of resonances was done from HSQC, HMBC, DOSY NMR experiments. Elemental analyses were performed on a LECO CHNS-932 instrument.

\subsection{Synthesis of Di-propargyl-curcumin (I)}

A solution of $0.08 \mathrm{~mL}$ acetylacetone $(0.79 \mathrm{mmol})$ and $0.04 \mathrm{~g}$ boron oxide $(0.55 \mathrm{mmol})$ was add over another solution of 3-methoxy-4-(2-propyloxy)-benzaldehyde (0.30 g, $1.58 \mathrm{mmol})$ and tributylborate $(0.85 \mathrm{~mL}, 3.16 \mathrm{mmol})$ after stirring each one during $30 \mathrm{~min}$ at $50{ }^{\circ} \mathrm{C}$. The combined mixture was heated at $50^{\circ} \mathrm{C}$ for another $15 \mathrm{~min}$. Subsequently, n-butylamine in EtOAc $(1 \mathrm{~mL})$ was add dropwise during a period of $10 \mathrm{~min}$ at $50^{\circ} \mathrm{C}$ and additionally stirred at $80{ }^{\circ} \mathrm{C}$ for $18 \mathrm{~h}$. After cooling to $50{ }^{\circ} \mathrm{C}$, preheated $\left(50^{\circ} \mathrm{C}\right)$ aqueous $\mathrm{HCl}$ solution $(3 \mathrm{~mL}, 0.4 \mathrm{M})$ was added and then stirred for another $60 \mathrm{~min}$ at the same temperature. The mixture was extracted several times with EtOAc and the combined organic layers were washes acid-free, dried over magnesium sulfate, filtrate and concentrated under reduced pressure. The residue was recrystallized from methanol $\left(-20^{\circ} \mathrm{C}\right)$ to give the corresponding orange product $(0.24 \mathrm{~g}, 69 \%) .{ }^{1} \mathrm{H}$ and ${ }^{13} \mathrm{C}-\mathrm{NMR}$ signals are consistent with the proposed structure and in accord with literature.

\subsection{Synthesis of (IMe $\left.{ }_{3} N S\right)_{4} G_{2}[$ curcumin $] G_{2}\left(\mathrm{SNMe}_{3} I\right)_{4}(\mathbf{1})$}

Over a solution of $0.03 \mathrm{~g}(0.06 \mathrm{mmol})$ of compound $\left(\mathrm{CH} \equiv \mathrm{CCH}_{2} \mathrm{O}\right)$ curcumin $\left(\mathrm{OCH}_{2} \mathrm{C} \equiv \mathrm{CH}\right)^{33}(\mathbf{I})$ in DMSO was added 2.2 equivalents $(0.17 \mathrm{~g}, 0.12 \mathrm{mmol})$ of $\mathrm{N}_{3} \mathrm{G}_{2}\left(\mathrm{SNMe}_{3} \mathrm{I}\right)_{4}(\mathbf{I I}), 2.2$ equivalents of $\mathrm{NEt}_{3}(0002 \mathrm{~mL}, 0011 \mathrm{mmol})$ and $5,3 \mathrm{mg}(0.003 \mathrm{mmol})$ of CuI. The resulting mixture was stirred at room temperature for $24 \mathrm{~h}$. Then, the solvent was removed under vacuum and the solid obtained was dissolved in water and purified by dialysis for one week using a dialysis membrane with a molecular weight cut off of $2000 \mathrm{Da}$ to give a brown solid corresponding to compound 1 (0.11 g, 61\%). ${ }^{1} \mathbf{H}-N M R$ (DMSO-d $)_{6}$ : $\delta(\mathrm{ppm})-0.08$ (s, 6H, SiCH $\left.H_{3}\right), 0.08\left(\mathrm{~s}, 12 \mathrm{H}, \mathrm{SiCH}_{3}\right), 0.60$ (m, 20H, $\mathrm{NCH}_{2} \mathrm{CH}_{2} \mathrm{CH}_{2} \mathrm{CH}_{2} \mathrm{Si}, \mathrm{SiCH}_{2} \mathrm{CH}_{2} \mathrm{CH}_{2} \mathrm{Si}$ ), 0.86 (m, 16H, $\left.\mathrm{SiCH}_{2} \mathrm{CH}_{2} \mathrm{~S}\right), 1.27$ (m, 12H, $\mathrm{NCH}_{2} \mathrm{CH}_{2} \mathrm{CH}_{2} \mathrm{CH}_{2} \mathrm{Si}, \mathrm{SiCH}_{2} \mathrm{CH}_{2} \mathrm{CH}_{2} \mathrm{Si}$ ), 1.82 (m, 4H, $\left.\mathrm{NCH}_{2} \mathrm{CH}_{2} \mathrm{CH}_{2} \mathrm{CH}_{2} \mathrm{Si}\right), 2.63$ (m, 16H, $\left.\mathrm{SiCH}_{2} \mathrm{CH}_{2} \mathrm{~S}\right), 2.90\left(\mathrm{~m}, 16 \mathrm{H}, \mathrm{SCH}_{2} \mathrm{CH}_{2} \mathrm{~N}\right), 3.08\left(\mathrm{~s}, 72 \mathrm{H}, \mathrm{N}\left(\mathrm{CH}_{3}\right)_{3}\right), 3.53\left(\mathrm{~m}, 16 \mathrm{H}, \mathrm{SCH}_{2} \mathrm{CH}_{2} \mathrm{~N}\right)$, 
$3.80\left(\mathrm{~m}, 6 \mathrm{H}, \mathrm{OCH}_{3}\right), 4,35\left(\mathrm{~m}, 4 \mathrm{H}, \mathrm{NCH}_{2} \mathrm{CH}_{2} \mathrm{CH}_{2} \mathrm{CH}_{2} \mathrm{Si}\right), 5,16\left(\mathrm{~m}, 4 \mathrm{H}, \mathrm{OCH}_{2}\right), 7.24-8.00(\mathrm{~m}, 11 \mathrm{H}$, $\left.\mathrm{C}_{6} H_{3}, \mathrm{C} H=\mathrm{CH}, \mathrm{COC} H=\mathrm{COH}\right) 8.26(\mathrm{~m}, 2 \mathrm{H}, \mathrm{C}=\mathrm{CH}-\mathrm{N})$. Elemental analysis $\mathrm{C}_{109} \mathrm{H}_{218} \mathrm{I}_{8} \mathrm{~N}_{14} \mathrm{O}_{6} \mathrm{~S}_{8} \mathrm{Si}_{6}$ (3261.26 $\mathrm{g} \mathrm{mol}^{-1}$ ) calcd. (\%): C, 40.14; H, 6.74; N, 6.01; S, 7.86. found: C, 40.25; H, 6.75; N, $6.00 ; \mathrm{S}, 7.84$.

\subsection{ABTS radical scavenging capacity (\%)}

The capacity to scavenge $\mathrm{ABTS}^{++}$was measured according to Wiriyaphan et al. ${ }^{35}$ Briefly, an $\mathrm{ABTS}^{++}$stock solution was prepared by mixing a $7.4 \mathrm{mM}$ solution of $\mathrm{ABTS}^{++}$and a $2.6 \mathrm{mM}$ solution of potassium persulfate in water. This solution was kept in the dark for $16 \mathrm{~h}$ at room temperature. An $\mathrm{ABTS}^{++}$working solution in DMSO was daily prepared, just before measuring, by dilution of the $\mathrm{ABTS}^{-+}$stock solution and adjustment of the absorbance at $0.70 \pm 0.01 \mathrm{UA}$. Next, $1.66 \mu \mathrm{L}$ of solution of sample ( $3 \mathrm{mM}$ in DMSO) was mixed with $98.33 \mu \mathrm{L}$ of the $\mathrm{ABTS}^{++}$ working solution, incubated in the dark for $6 \mathrm{~min}$ and the absorbance corresponding to ABTS radicals was measured at $734 \mathrm{~nm}$. Scavenge capacity of samples was determined as equation 1 :

$$
A B T S^{*+} \text { radical scavenging capacity }(\%)=\frac{\text { Abs blank }- \text { Abs }_{\text {sample }}}{\text { Absblank }} \times 100
$$

Equation 1: Inhibition of ABTS radical scavenging activity.

where $\mathrm{Abs}_{\text {sample }}$ is the absorbance of $1.66 \mu \mathrm{L}$ of sample with $98.33 \mu \mathrm{L}$ of ABTS ${ }^{+}{ }^{+}$working solution and $\mathrm{Abs}_{\text {blank }}$ is the absorbance of $1.66 \mu \mathrm{L}$ of solvent (DMSO) with $98.33 \mu \mathrm{L}$ of $\mathrm{ABTS}^{\bullet+}$ working solution (without samples).

\subsection{Cell culture and MTT assays for MCF-7 cells}

The human breast adenocarcinoma cell line MCF-7 utilized in this assay was kindly donated by Unidad de Cultivos at the University of Alcalá. Cells were grown routinely in DMEM (Dulbecco's modified Eagle Medium) with 10\% fetal bovine serum (FBS) and 1\% penicillin/streptomycin/amphotericin B (all from Sigma-Aldrich) at $37{ }^{\circ} \mathrm{C}$ and $5 \% \mathrm{CO}$. Cells were seeded in 24-well plates (Nunclon Delta Surface, Thermo Fischer Scientific) as monolayers $(20,000$ cells/well) and grown for $48 \mathrm{~h}$ in complete medium $(500 \mu \mathrm{L})$. Solutions of compounds were prepared by diluting a freshly prepared stock solution in DMSO of the corresponding compound in aqueous medium (DMEM). Afterward, the intermediate dilutions of the compounds were serially diluted to the appropriate concentration (ranging from 0 to $100 \mu \mathrm{M}$ ) and the cells were incubated for another $24 \mathrm{~h}$ DMSO at comparable concentrations did not show any effects on cell cytotoxicity. Cytotoxicity was determined using the MTT assay (MTT 3-(4,5dimethyl 2thiazolyl)-2,5-diphenyl-2H-tetrazolium bromide). Subsequently, MTT (1:10 of $5.0 \mathrm{mg} / \mathrm{mL}$ solution) was added to the cells and the plates were incubated for a further $3.5 \mathrm{~h}$. Then the culture medium was removed and the purple formazan crystals formed by the mitochondrial 
dehydrogenase and reductase activity of alive cells were dissolved in DMSO. The optical density, directly proportional to the number of surviving cells, was quantified at $570 \mathrm{~nm}$ (background correction at $690 \mathrm{~nm}$ ) using a multiwell plate reader (ELX800 Bio-Teck instrument) and the fraction of surviving cells was calculated from the absorbance of untreated control cells. The $\mathrm{IC}_{50}$ value was calculated as the concentration reducing the proliferation of the cells by $50 \%$ and is presented as a mean $( \pm \mathrm{SE})$ from three independent experiments, each comprising three microcultures per concentration level.

\subsection{Determination of intracellular ROS using the DCFH Assay}

The fluorogenic dye 2',7'-dichlorodihydrofluorescein diacetate (DCFH-DA) (Invitrogen D-399) is deacetylated by cellular esterases to the 2',7'-dichlorodihydrofluorescein (DCFH) anion, which is retained in the cell and later oxidized by ROS into fluorescent 2', 7'-dichlorofluorescein (DCF) product. To detect intracellular ROS production, tert-butyl hydroperoxide (TBHP) and Nacetylcysteine (NAC) were used as oxidizing and antioxidant control agents respectively. MCF7 cells were seeded in 6-well plates $\left(2 \times 10^{5}\right)$ and cultured at $37^{\circ} \mathrm{C}$ in $5 \% \mathrm{CO}_{2}$ for $48 \mathrm{~h}$. Solutions of compounds were prepared in DMSO, add to the cell to a final concentration of 2.75 and 0.55 $\mathrm{mM}$ and incubated for another $24 \mathrm{~h}$. On the day of the experiment, negative control sample was prepared incubating the cells with NAC (final concentración: $375 \mathrm{mM}$ ) for $1 \mathrm{~h}$. Afterwards, cells were washed, resuspended in complete growth media, and treated with DCFH-DA (Stock: 5Mm. Tincion solution: $8 \mathrm{ml}+10 \mathrm{ul}$ de stock solution) during $30 \mathrm{~min} / 37^{\circ} \mathrm{C}$. After DCFH-DA was removed, the control and treated cells were exposed to TBHP $(690 \mu \mathrm{M})$ for $10 \mathrm{~min}$. Then, fluorescence was measured in presence of propidium iodide (for exclusion of dead cells) (final concentration: $10 \mathrm{mg} / \mathrm{ml}$ ) using a FACS calibur Flow cytometer (Becton Dickinson, San Jose, CA) and analysed by Flow Jo software (Tree Star, Ashland, OR) Cyflogic v 1.2.1 program. Three different wells were analysed for each concentration of oxidative stress-inducing agents or antioxidants, and three replicates were performed for each experiment.

\subsection{Cell cycle assays}

MCF-7 cells $\left(2 \times 10^{5}\right)$ were grown in 6-well plates for $48 \mathrm{~h}$., treated with dendrimer and incubated for another $24 \mathrm{~h}$. Then, the cells were washed with PBS and detached with trypsin. Cells were centrifuged at $1300 \mathrm{rpm}$ for $5 \mathrm{~min}$ at $4^{\circ} \mathrm{C}$ and the pellets were mixed with ice-cold $70 \%$ ethanol and then kept at $-20^{\circ} \mathrm{C}$ for $30 \mathrm{~min}$. After removing the ethanol by centrifugation, the pellets were washed with PBS and centrifuged again. The supernatants were discarded and the pellets suspended in PBS, $0.2 \mathrm{mg} / \mathrm{ml}$ RNase A and $20 \mu \mathrm{g} / \mathrm{ml}$ PI before flow cytometry analysis with a cytometer above mentioned. Results obtained were analyzed with the Cyflogic v 1.2.1 program.

\section{RESULT AND DISCUSSION}




\subsection{Synthesis and characterization}

In order to evaluate the possibility of introducing curcumin into the dendritic macromolecule by covalent linkage, from the synthetic point of view, the simplest possibility was to employ a "bowtie" topology system where curcumin was used as a core through dendronization of the curcumin phenol groups. The coupling of the dendritic wedges to the curcumin molecule was performed through Huisgen cycloaddition ("click chemistry" reaction) of azide-terminated carbosilane wedge (II) previously reported in our research group ${ }^{34}$ with a curcumin derivative where the hydroxy substituents on two aromatic rings were replaced by propargyl group (I). The propargylic derivative of curcumin (I) was previously described, ${ }^{36}$ but a different methodology was necessary to use due to its low yield. The new synthesis was carried out according to the slightly modified version of Pabon's method, ${ }^{37}$ as described in Scheme 1, starting from 3-methoxy-4-(2propyloxy)-benzaldehyde ${ }^{33}$ and acetylacetone.

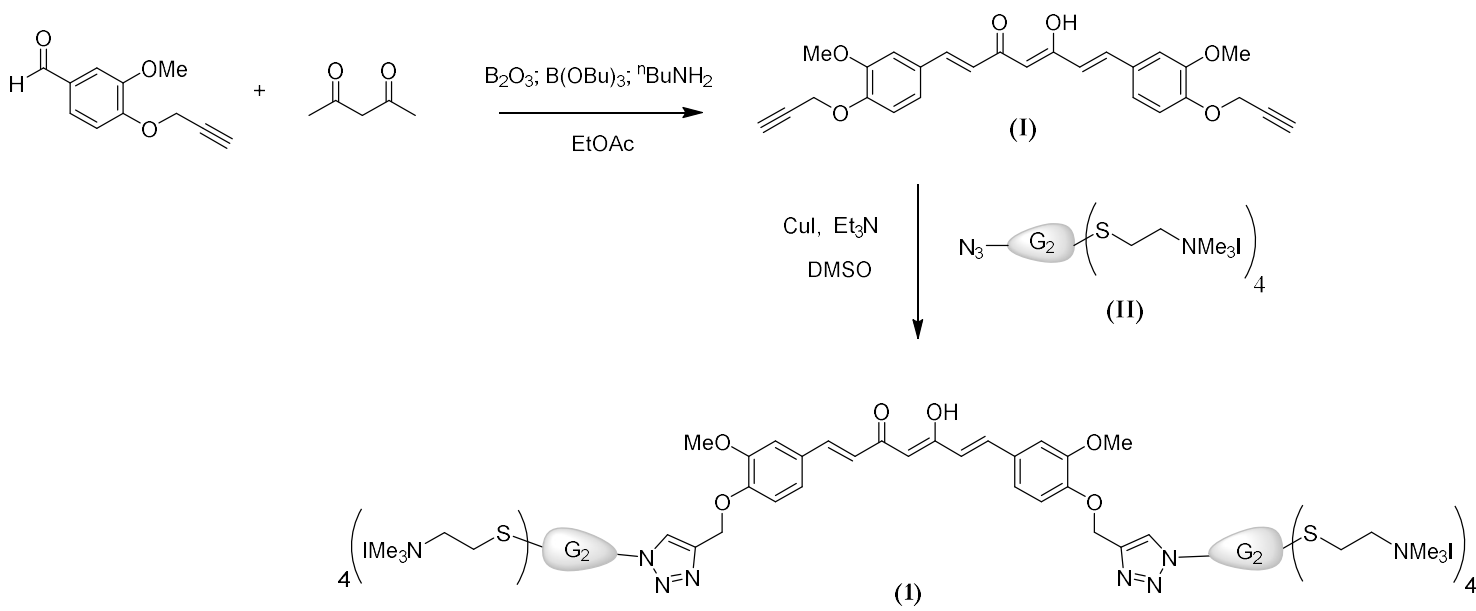

Scheme 1. Synthesis of $\left(\mathrm{IMe}_{3} \mathrm{NS}\right)_{4} \mathrm{G}_{2}[$ curcumin $] \mathrm{G}_{2}\left(\mathrm{SNMe}_{3} \mathrm{I}\right)_{4}(\mathbf{1})$

The reaction was performed using anhydrous EtOAc as solvent by addition of a solution of acetylacetone and boron oxide over another solution of 3-methoxy-4-(2-propyloxy)benzaldehyde and tributylborate, both solutions were pre-heated at $50{ }^{\circ} \mathrm{C}$ for 30 minutes. Then, the resulting mixture was maintained for another 15 minutes at the same temperature. Subsequently, a solution of n-butylamine in EtOAc was prepared and slowly added to the above mixture and kept at $80{ }^{\circ} \mathrm{C}$ for $18 \mathrm{~h}$. After, the temperature was lowered to $50^{\circ} \mathrm{C}$, hot $\mathrm{HCl}\left(50{ }^{\circ} \mathrm{C}\right)$ was added and stirred for 60 minutes at this temperature to afford the corresponding system $\mathbf{I}$ as an orange solid in good yield. Representative signals in the ${ }^{1} \mathrm{H}-\mathrm{NMR}$ spectrum for compound $\mathbf{I}$ are the disappearance of the singlet corresponding to the aldehyde group of the vanillin analogue precursor and the exhibition of new resonances at 7.56 and $6.83 \mathrm{ppm}$ for the $-\mathrm{CH}$ - groups of the double bonds formed. Furthermore, it was observed at $6.10 \mathrm{ppm}$ the proton of the unsaturated bond characteristic of the enol tautomer, which confirm the existence of only the enolic species 
of the two possible tautomers of curcumin. ${ }^{13} \mathrm{C}-\mathrm{NMR}$ data are in agreement with the ${ }^{1} \mathrm{H}-\mathrm{NMR}$ spectrum, and the most significant signals are those corresponding to the carbon of the central methine group at $100.5 \mathrm{ppm}$, olefinic groups located at 121.9 and $139.6 \mathrm{ppm}$ and the resonances for the propargyl fragment at 78.0 and $55.5 \mathrm{ppm}$.

The CuAAC reaction of propargyl curcumin with azide functionalized carbosilane dendron $\mathrm{N}_{3} \mathrm{G}_{2}\left(\mathrm{SNMe}_{3} \mathrm{I}\right)_{4}$ (II) leads to $\left(\mathrm{IMe}_{3} \mathrm{NS}\right)_{4} \mathrm{G}_{2}$ [curcumin $] \mathrm{G}_{2}\left(\mathrm{SNMe}_{3} \mathrm{I}\right)_{4}$ (1) through a Huisgen cycloaddition using a $\mathrm{Cu}(\mathrm{I})$ catalyst in $\mathrm{DMF}$ as solvent, as a water-soluble brown solid in moderate yields. The new compound was characterized by NMR and elemental analysis (see Supporting information Figure S1 and S2). Also, the DOSY experiment showed only the presence of one compound in solution indicating the connectivity between the fragments. These spectra show the disappearance of the alkyne units and the appearance of the triazole ring showed by a singlet at $8.26 \mathrm{ppm}$ corresponding to the proton of the triazole (c) and two multiplets located at 4.35 (d) and $5.16 \mathrm{pm}$ (b) corresponding to methylene groups adjacent to the triazole unit. The signals corresponding to outer chain $\mathrm{S}\left(\mathrm{CH}_{2}\right)_{2} \mathrm{NMe}_{3} \mathrm{I}$ of carbosilane wedge showed two multiplets at $\delta 2.90$ and 3.53 for the protons of the $\mathrm{SCH}_{2}$ and the $\mathrm{CH}_{2} \mathrm{~N}$ groups, respectively, whereas a singlet at $\delta 3.08$ confirmed the presence of the trimetylammonium group.

\subsection{Determination of anticancer and antioxidant activity}

Since curcumin has demonstrated to possess multifaceted therapeutic and pharmacologic effects such as non-toxic, highly antioxidant, and anti-inflammatory and anticancer activity, there are several studies concerning their use as therapeutic agent. Among them, we focused on its antitumor and antioxidant properties. The potential of $\mathbf{1}$ as anticancer agent was investigated by measuring in vitro cytotoxicity in terms of half-maximal inhibitory concentration $\left(\mathrm{IC}_{50}\right)$ on the breast adenocarcinoma cell line (MCF-7 cells). Several studies have also reported the cytotoxic effects of curcumin on almost all types of cancer, ${ }^{6}$ however the specific mechanism of curcumininduced cytotoxicity still remain unclear due to the different evidences that involve anti- and proapoptotic signaling pathways in different cell types. ${ }^{38,39}$ In particular, recent studies have shown that curcumin, either alone or in combination with other anticancer agents, can efficiently induce an apoptotic mechanism in MCF-7 cells. ${ }^{40,}{ }^{41}$ The cytotoxic activity of the new curcumin derivative 1 was assayed by monitoring their ability to inhibit cell growth using the MTT assay. The result for 1 shows a growth-inhibitory activity with a $\mathrm{IC}_{50}=2.75 \pm 0.11 \mu \mathrm{M}$ lower than free curcumin $\left(\mathrm{IC}_{50}=14.09 \pm 0.01 \mu \mathrm{M}\right)$ and the analogue dendron $\mathrm{N}_{3} \mathrm{G}_{2}\left(\mathrm{SNMe}_{3} \mathrm{I}\right)_{4}(\mathrm{II})(9.83 \pm 0.53$ $\mu \mathrm{M}$ ) which surprisingly also shows anticancer activity. These data can suggest either the existence of a cooperative effect between curcumin and the cationic dendrons or an increase of curcumin bioavailability as result of its solubilization in water. To investigate the cellular death mechanism induced by $\mathbf{1}$, the cell cycle perturbation was analyzed by flow cytometry after treatment of MFC- 
17 cells for $24 \mathrm{~h}$ with different concentrations $(0.08,0.55$ and $2.75 \mu \mathrm{M})$ of compound 1 . The results

2 obtained in the cell cycle did not show any significant number of cells in SubG0 phase (see Figure

3 3) indicating a non-apoptotic pathway. Similar results have been observed when curcumin was

4 dendronized with polyester dendrons of second generation where the mechanism of cellular death

5 was not apoptotic in C6 glioma cell line ${ }^{32}$. Analogously, other synthetic derivatives of curcumin

6 like hydrazinobenzoylcurcumin induced A549 cell autophagy. ${ }^{42}$ Interestingly, the dendron

$7 \quad \mathrm{~N}_{3} \mathrm{G}_{2}\left(\mathrm{SNMe}_{3} \mathrm{I}\right)_{4}$ (II) also did not afford any apoptotic pathway (data no shown). This fact

8 indicates that $\mathbf{1}$ drives cellular death via a non-apoptotic mechanism acting by a different

9 mechanism than free curcumin and suggesting that the presence of dendritic carbosilane wedges

10 could be implicated in the mechanism of death.
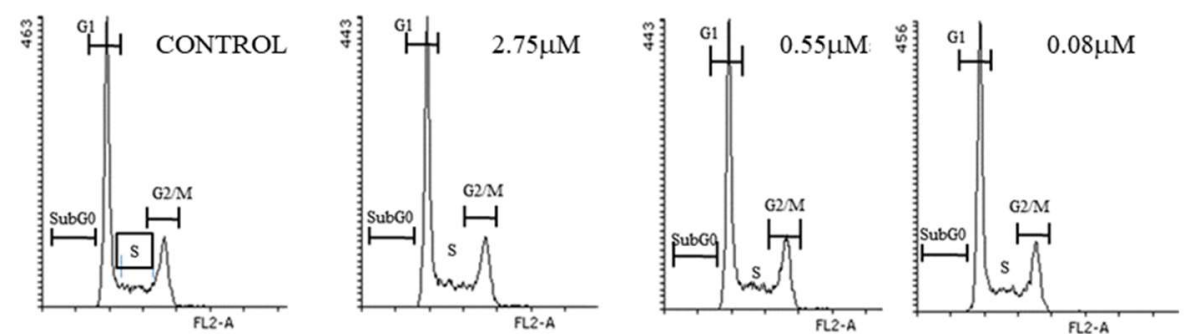

Figure 3. Histograms of cell cycle in MCF-7 cells after treatments with the derivative $\left(\mathrm{IMe}_{3} \mathrm{NS}_{4} \mathrm{G}_{2}[\right.$ curcumin $] \mathrm{G}_{2}\left(\mathrm{SNMe}_{3} \mathrm{I}\right)_{4}(\mathbf{1})$ at different concentrations $(2.75,0.55$ and $0.08 \mu \mathrm{M})$

In relation to the antioxidant activity, although the exact mechanism by which curcumin is able to trap radicals remains under investigations, many theoretical and experimental studies agreed on the importance of phenolic group. However, it seems to depend on the type of ROS radical or species studied and not exclusively on the nature of the substituents located on the aromatic rings. ${ }^{43}$ The antioxidant activity of the dendritic wedge II, free curcumin and compound $\mathbf{1}$ containing cationic carbosilane dendrons, was evaluated by ABTS radical scavenging test. For compound 1 , the percentage of inhibition obtained was $94.8 \%$, practically the same percentage as shown by free curcumin $(96.1 \%)$ under the same conditions (see Table 1).

Table 1. Antioxidant ${ }^{1}$ and anticancer ${ }^{2}$ activities of the free curcumin, dendronized curcumin $\mathbf{1}$ and dendron (II) derivatives

\begin{tabular}{ccc}
\hline Compound & $\begin{array}{c}\text { radical scavenging (\%) } \\
\text { ABTS }\end{array}$ & $\begin{array}{c}\mathbf{I C}_{\mathbf{5 0}} \boldsymbol{\mu g} / \mathbf{m L} \pm \mathbf{S D} \\
\mathbf{M C F}-\mathbf{7}^{\mathbf{2}}\end{array}$ \\
\hline $\mathbf{1}$ & 94.8 & $2.75 \pm 0.11$ \\
\hline Curcumin [CUR] & 96.1 & $14.01 \pm 0.01$ \\
\hline Dendron II & 95.8 & $9.83 \pm 0.53$ \\
\hline
\end{tabular}


3 It is worth to say that the free dendron $\mathrm{N}_{3} \mathrm{G}_{2}\left(\mathrm{SNMe}_{3} \mathrm{I}\right)_{4}$ (II) also showed an antioxidant behavior 4 with an inhibition value of $95.8 \%$, probably as consequence of the presence of iodide counteranions which are known to have an important role as antioxidant. ${ }^{44}$ Although probably the antioxidant capacity of $\mathbf{1}$ comes from the existence of ammonium terminated dendrons containing iodide as counter-anion, it cannot be ruled out that such radical scavenging activity can be also produced by the curcumin moiety or a combination of both. Recently, the dendronization of curcumin by ester dendrons making the two phenol groups unavailable, exerted antioxidant properties, suggesting a different redox mechanism compared to the free curcumin. ${ }^{32}$ In addition, intracellular ROS protection efficiency and free radical-scavenging activity of curcumin derivative 1 was also determined from an in vitro experiment in MFC-7 cell line by flow cytometry using the oxidant-sensing fluorescent probe $2^{\prime}, 7^{\prime}$-dichlorodihydrofluorescein diacetate (DCFH-DA). It is possible to determine the levels of endogenous ROS formation when the oxidative stress was induced by tert-butyl hydroperoxide (TBHP). To evaluate the antioxidant activity is necessary a pre-treatment of the MFC-7 cells with $\mathbf{1}$, II and free curcumin in order to ensure the internalization of the compounds inside the cells. The concentrations used are below the $\mathrm{IC}_{50}$ of $\mathbf{1}\left(\mathrm{IC}_{50}=2.75 \pm 0.11 \mu \mathrm{M}\right)$ and acetylcysteine (NAC) was used as a positive control for the antioxidant activity. As expected, the compound 1 showed a free radical-scavenging activity to provoke a significantly reduction of ROS levels, being more active than free curcumin and dendritic wedge II independently (Figure 4). Again, it gets highlighted the existence of a possible cooperative effect between curcumin and the cationic dendrons.

Intracellular ROS protection activity

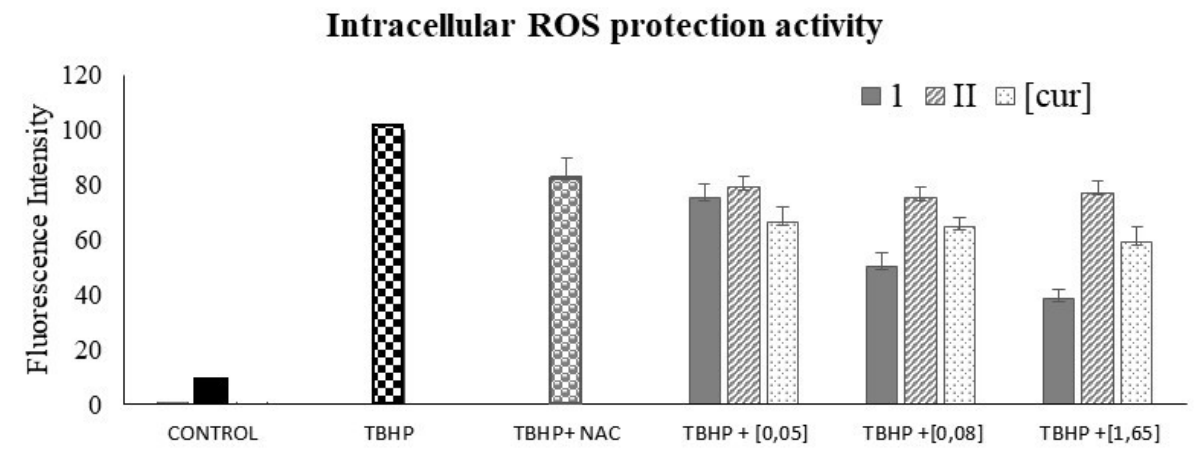

Figure 4. DCFH-DA fluorescence assay used to measure intracellular ROS by flow cytometry in MCF-7 cells. All samples were first incubated (24 h.) with different concentration of free curcumin, $\mathbf{1}$ and $\mathbf{I I}(0.05 ; 0.08$ and $1.65 \mu \mathrm{M})$ prior the addition of the ROS stimulating agent (TBHP). NAC is an antioxidant positive control.

\section{CONCLUSIONS}


To summarize, this work reports on the synthesis and characterization of a new bow-tie cationic carbosilane system with curcumin at the core by an efficient Huisgen cycloaddition of azideterminated carbosilane cationic dendrons and a propargylic derivate of curcumin in good yield. The new derivative (IMe $3 \mathrm{NS}_{4} \mathrm{G}_{2}[$ curcumin $] \mathrm{G}_{2}\left(\mathrm{SNMe}_{3} \mathrm{I}\right)_{4}(\mathbf{1})$ is soluble in water making possible to increase the bioavailability of curcumin in physiological medium. The in vitro cytotoxicity data of $\mathbf{1}$ shows a more potent inhibitory activity against breast cancer cells with lower $\mathrm{IC}_{50}$ values $(2.75 \mu \mathrm{M})$ than the free curcumin and the dendritic wedge II. This result may suggest a cooperative effect between both moieties of the molecules. The study of the cell cycle in MCF-7 cells reveled non-apoptotic pathways for the mechanism of cellular death both for $\mathbf{1}$ and dendron II, while for the free curcumin in the same types of cells an apoptotic mechanism is presented. Probably the presence of the dendritic wedges in the molecule modulates the mechanism of cellular death. On the other hand, respecting the antioxidant properties of $\mathbf{1}$, the radical scavenging assays showed that the new dendronized curcumin derivative $\mathbf{1}$ present an efficient antioxidant property at concentrations below its $\mathrm{IC}_{50}$ and causes a greater decrease of radical free than the free curcumin and dendron II, suggesting again a cooperative effect between both fragments. In addition, the substitution of the phenolic groups of curcumin by carbosilane dendrons does not eliminate the antioxidant capacity. All these results suggest that the presence of dendritic wedges in the curcumin structure play an important role in the anticancer and antioxidant properties. A possible relationship between antioxidant and anticancer activities of compound $\mathbf{1}$ can be inferred since one of the causes of death by apoptosis is the excess of ROS. The reduction or elimination of free radicals by $\mathbf{1}$ may help to modify the mechanism of action toward a non-apoptotic one. Therefore, the antioxidant activity and the higher cytotoxicity in MFC-7 cell line suggest this compound as a newly promising anti-breast cancer agent. Future works are in progress to deeply understand the cell death mechanism induced by compound $\mathbf{1}$.

\section{ACKNOWLEDGEMENTS}

This work has been supported by grants CTQ-2014-54004-P and CTQ2011-29336-CO3-O1 (from MINECO), CCG2014/EXP046 (from UAH), Consortium NANODENDMED ref S2011/BMD-2351 (CM) and IMMUNOTHERCAN-CM (B2017/BMD3733). CIBER-BBN as an initiative funded by the VI National R\&D\&i Plan 2008-2011, Iniciativa Ingenio 2010, Consolider Program, CIBER Actions and financed by the Instituto de Salud Carlos III with assistance from the European Regional Development Fund.

\section{REFERENCES}

1. C. Printz, Cancer, 2017, 123, 1085.

2. K. C. Aalders, K. Tryfonidis, E. Senkus and F. Cardoso, Cancer Treat. Rev., 2017, 53, 98. 
3. K. Athreya and S. Ali, Transl. Cancer Res. , 2017, 6, 30.

4. V. L. Maruthanila, R. Elancheran, A. B. Kunnumakkara, S. Kabilan and J. Kotoky, Breast Cancer, 2017, 24, 191.

5. S. Nagini, Anticancer Agents Med. Chem., 2017, 17, 152.

6. A. Allegra, V. Innao, S. Russo, D. Gerace, A. Alonci and C. Musolino, Cancer. Invest., 2017, 35, 1 .

7. D. Lelli, C. Pedone and A. Sahebkar, Biomed. Pharmacother., 2017, 88, 832.

9. Z.-D. Lv, X.-P. Liu, W.-J. Zhao, Q. Dong, F.-N. Li, H.-B. Wang and B. Kong, Int. J Clin. Exp. Pathol., 2014, 7, 2818.

11. E. I. Medina-Reyes, D. Garcia-Viacobo, F. A. Carrero-Martinez and Y. I. Chirino, Crit. Rev. Ther. Drug Carrier Syst., 2017, 34, 35.

12. N. Asadi, S. Davaran, Y. Panahi, A. Hasanzadeh, J. Malakootikhah, H. F. Moafi and A. Akbarzadeh, Artif. Cells Nanomed. Biotechnol., 2017, 45, 18.

13. R. I. Mahran, M. M. Hagras, D. Sun and D. E. Brenner, The AAPS Journal, 2017, 19, 54.

14. D. H. Yang, H. J. Kim, J. K. Kim, H. J. Chun and K. Park, J Ind. Eng. Chem., 2017, 45, 156.

15. E. Marin, M. I. Briceno, A. Torres and C. Caballero-George, Planta Med., 2017.

16. Z. Hussain, H. E. Thu, S.-F. Ng, S. Khan and H. Katas, Colloids Surf. B Biointerfaces, 2017, 150, 223.

17. M. Z. Lin, L. L. Teng, Y. Wang, J. X. Zhang and X. L. Sun, Drug Deliv., 2016, 23, 1420.

18. J. Singh, K. Jain, N. K. Mehra and N. K. Jain, Artif. Cells Nanomed. Biotechnol., 2016, 44, 1626.

19. M. Selin, L. Peltonen, J. Hirvonen and L. M. Bimbo, 2016, 34, 10.

20. L.-p. Wu, M. Ficker, J. B. Christensen, P. N. Trohopoulos and S. M. Moghimi, Bioconjug. Chem., 2015, 26, 1198.

21. D. Sepulveda-Crespo, J. Luis Jimenez, R. Gomez, F. Javier De La Mata, P. L. Majano, M. Angeles Munoz-Fernandez and P. Gastaminza, Nanomed Nanotechnol., 2017, 13, 49.

22. E. Vacas-Cordoba, M. Maly, F. J. De la Mata, R. Gomez, M. Pion and M. Angeles Munoz-Fernandez, Int. J. Nanomed., 2016, 11, 1281.

23. G. Mencia, N. Sanz del Olmo, L. Munoz-Moreno, M. Maroto-Diaz, R. Gomez, P. Ortega, M. Jose Carmena and F. Javier de la Mata, New J. Chem., 2016, 40, 10488.

24. I. Heredero-Bermejo, J. Sanchez-Nieves, J. Soliveri, R. Gomez, F. J. de la Mata, J. L. Copa-Patino and J. Perez-Serrano, 2016, 509, 1. 
25. I. Bravo-Osuna, M. Vicario-de-la-Torre, V. Andres-Guerrero, J. Sanchez-Nieves, M. Guzman-Navarro, F. J. de la Mata, R. Gomez, B. de las Heras, P. Argueso, G. Ponchel, R. Herrero-Vanrell and I. T. Molina-Martinez, Mol. Pharm., 2016, 13, 2966.

26. K. Milowska, A. Szwed, M. Mutrynowska, R. Gomez-Ramirez, F. Javier de la Mata, T. Gabryelak and M. Bryszewska, Int. J. Pharm., 2015, 484, 268.

27. D. Marson, E. Laurini, P. Posocco, M. Fermeglia and S. Pricl, Nanoscale, 2015, 7, 3876.

28. L. Wang, X. Xu, Y. Zhang, Y. Zhang, Y. Zhu, J. Shi, Y. Sun and Q. Huang, J. Mater. Sci. Mater. Med, 2013, 24, 2137.

29. M. Mollazade, K. Nejati-Koshki, A. Akbarzadeh, N. Zarghami, M. Nasiri, R. JahanbanEsfahlan and A. Alibakhshi, Asian Pac. J Cancer Prev., 2013, 14, 6925.

30. P. Kesharwani, L. Xie, S. Banerjee, G. Mao, S. Padhye, F. H. Sarkar and A. K. Iyer, Colloids Surf. B Biointerfaces, 2015, 136, 413.

31. D. Shawon, S. Darin, D. Sukanta, S. Chong, A. Saadyah, R. Krishnaswami and E. F. Jimmie, Anticancer Agents Med. Chem., 2013, 13, 1531.

32. J. M. Landeros, F. Belmont-Bernal, A. T. Pérez-González, M. I. Pérez-Padrón, P. Guevara-Salazar, I. G. González-Herrera and P. Guadarrama, Mat. Sc.i Eng. C-Mater., $2017,71,351$.

33. R. Pingaew, P. Mandi, C. Nantasenamat, S. Prachayasittikul, S. Ruchirawat and V. Prachayasittikul, Eur. J. Med. Chem, 2014, 81, 192.

34. E. Fuentes-Paniagua, C. E. Pena-Gonzalez, M. Galan, R. Gomez, F. J. de la Mata and J. Sanchez-Nieves, Organometallics, 2013, 32, 1789.

35. C. Wiriyaphan, B. Chitsomboon and J. Yongsawadigul, Food Chem. , 2012, $132,104$.

36. D. d. C. F. Gomes, L. V. Alegrio, M. E. F. d. Lim, L. L. Leon and C. A. C. Araújo, Arzneimittelforschung, 2002, 52, 120.

37. H. Y. Y. Pabon, Recl. Trav. Chim. Pays-Bas, , 1964, 83, 379.

38. H.-O. Pae, S.-O. Jeong, G.-S. Jeong, K. M. Kim, H. S. Kim, S.-A. Kim, Y.-C. Kim, S.D. Kang, B.-N. Kim and H.-T. Chung, Biochem. Biophys. Res. Commun, 2007, 353, 1040.

39. S. Reuter, S. Eifes, M. Dicato, B. B. Aggarwal and M. Diederich, Biochem. Pharmacol. , 2008, 76, 1340 .

40. Y. Akkoc, O. Berrak, E. D. Arisan, P. Obakan, A. Coker-Gurkan and N. Palavan-Unsal, 2015, 71, 161 .

41. K. Mohankumar, S. Pajaniradje, S. Sridharan, V. K. Singh, L. Ronsard, A. C. Banerjea, C. S. Benson, M. S. Coumar and R. Rajagopalan, 2014, 210, 51.

42. G.-Z. Zhou, S.-N. Zhang, L. Zhang, G.-C. Sun and X.-B. Chen, Pharm. Biol. , 2014, 52, 111.

43. U. Singh, A. Barik, B. G. Singh and K. I. Priyadarsini, Free Radic. Res., 2011, 45, 317.

44. R. Winkler, Natural Science, 2015, 07, 10. 
